\title{
Effect of breed on botanical composition of cattle diets on Chihuahuan desert range
}

\author{
J. A. WINDER, D. A. WALKER, AND C. C. BAILEY
}

Authors are associate professor, former graduate student, and senior research assistant, Department of Animal and Range Sciences, New Mexico State University, Las Cruces, NM 88003.

\begin{abstract}
Fecal microhistology was used to estimate botanical composition of samples taken from Hereford $(N=11)$, Angus $(N=11)$ and Brangus (N=37) 3 to 5 year-old cows in 3 seasons (October, 1991 and January and July, 1992) and from Hereford $(N=10)$, Angus $(\mathrm{N}=9$ ) and Brangus $(\mathrm{N}=34)$ calves in October. Breed differences in botanical composition of diets and relationships between dam and offspring botanical composition of diets were examined. Breed differences were observed for cows in all 3 seasons and for calves in October. Brangus cows showed greater preference $(P<0.05)$ for Sporobolus than Hereford cows in October, January, and July. Brangus cows also showed greater preference for Sporobolus than Angus cows in January and July. Brangus and Angus calves showed greater preference for Sporobolus than Hereford calves in October $(P<0.05$ ). Brangus cows had a stronger preference for Yucca and total shrubs in January than either Hereford or Angus cows. Hereford cows and calves had stronger preference for Aristida than either Angus or Brangus in October $(P<0.05)$. Regression of October calf botanical components on dam botanical components indicated significant relationships for only 2 genera, Aristida $(P<0.01)$ and Sporobolus $(P<0.06)$. These data suggest that genetic composition of the animal is an important factor determining utilization of key plant species on Chihuahuan desert ranges.
\end{abstract}

Key Words: cattle, breeds, diets, range

In the Chihuahuan desert, stocking rates range from 25 to 65 ha per animal unit year long. The large land area per cow dictates low capital investment per unit of land. Thus, methods of controlling grazing cattle distribution may not be economically feasible. However, these range ecosystems are very susceptible to damage due to spot over-grazing and(or) species selectivity by grazing beef cattle. Because these ranges possess numerous palatable grasses, forbs, and shrubs, cattle diets tend to be complex, varying from season to season (Herbel and Nelson 1966b, Rosierre et al. 1975a; Rosierre et al. 1975b). If differences among cattle in dietary preference are partially genetically controlled, breed selection may be a mechanism for the more efficient utilization of Chihuahuan desert ranges and other similar sites. Little research has been conducted relative to potential genetic differences in

Minuscript accepted 10 June 1995. diet selectivity among breeds. In eastern Colorado, Walker et al. (1981) observed no important differences among diets of Hereford, Hereford $x$ Charolais, and Hereford x Angus cattle. However, Herbel and Nelson (1966b) observed some important differences between diets selected by Hereford and Santa Gertrudis cows in the Chihuahuan Desert. Breed differences have also been noted in diets selected by small ruminants (Warren et al. 1984).

Today, more than 85 breeds of cattle are known to exist in the U.S. (Taylor 1994). This represents a tremendous reservoir of germplasm and potential genetic variation. If large differences in diet selection exist among breeds of cattle, selection of breed may represent a cost effective, low input mechanism for altering range utilization.

The objectives of this study were 1) to evaluate the effect of breed on the botanical composition of diets selected by cows during three seasons, 2) to evaluate the effect of breed on botanical composition of diets selected by suckling calves, and 3 ) to evaluate the relationship between the botanical composition of cow and calf diets before weaning.

\section{Materials and Methods}

\section{Study Area}

This study was conducted during October 1991, January 1992, and July 1992 at the New Mexico State University College Ranch located $40 \mathrm{~km}$ north of Las Cruces. A single 1,400 ha pasture was used for this experiment. The location is a typical Chihuahuan desert site with long term average annual precipitation of 234 $\mathrm{mm}$. Annual precipitation was 444 and $411 \mathrm{~mm}$ in 1991 and 1992 , respectively. Mean annual temperature was $16^{\circ} \mathrm{C}$. June was the hottest month with an average temperature of $36.8^{\circ} \mathrm{C}$, whereas January was the coldest month with an average temperature of $13^{\circ} \mathrm{C}$. Principle forage species in the study area were mesa dropseed (Sporobolus flexuosus [Thurb.] Rydb.), black grama (Bouteloua eripoda [Torr.] Torr.), tobosa (Pleurophis mutica Buckl.), and leatherweed croton (Croton pottsii [Klotzsch] Muell.-Arg.). Other common plant species in the study area were broom snakeweed (Gutierrezia sarothrae [Pursh] Britt. and Rusby), honey mesquite (Prosopis glandulosa Torr.), and soap tree yucca (Yucca elata Engelm.).

Standing crop was estimated for grasses and forbs within 5 days of animal sampling. Four clippings were taken at each of 13 reference points in the study pasture. Reference points were 500 
$\mathrm{m}$ apart in east-west direction and $1000 \mathrm{~m}$ apart in north-south direction. At each reference point, a random direction and a random number of steps between sampling frames was determined. Plants were clipped at ground level within a $0.6 \times 0.3 \mathrm{~m}$ frame at each sampling point ( 4 per reference point). Samples were separated by species. Samples were dried in a forced air oven at $50^{\circ} \mathrm{C}$ for 96 hours. Total standing crop was calculated by weighing each sample and adding species together.

\section{Experimental Animals}

Cattle used in this experiment were 3 to 5 year-old purebred cows and their calves including 37 Brangus cows (only 34 calves were available), 11 Angus cows, and 11 Hereford cows. All cows were reared on the ranch. Replacement heifer development was consistent within age groups across breed, and cows had grazed the ranch for at least 2 years prior to initiation of this study. Cows calved between 1 January and 24 April, 1991 and calves were weaned on 15 October 1991. Cows and calves were placed into a common pasture 2 weeks before initiation of sampling. Previously grazed pastures were similar to the study pasture. Cows received no supplemental feed before or during the sampling periods. On 8 October 1991, 7 January 1992, and 15 July 1992 all cattle were gathered by 0900 hours. Weight, height, body condition score, and fecal grab sample were taken from each cow in each period. Fecal grab samples were only taken from the calves on 8 October 1991.

\section{Laboratory Methods}

Fecal samples were dried in a forced air oven at $50^{\circ} \mathrm{C}$ for 7 days then ground in a Wiley mill to pass a $1-\mathrm{mm}$ screen. Percentage of fecal organic matter nitrogen was determined by the Kjeldahl method (AOAC 1984), and organic matter phosphorus was determined by spectrophotometric calorimetric method (AOAC 1984). Botanical composition of feces was determined by microhistology (Sparks and Malechek 1968; Holechek 1982; Holechek and Gross 1982; Dabo et al. 1986). Dricd samples were ground in a Wiley mill to pass a 1-mm screen and then were analyzed by the AAFAB Composition Laboratory in Fort Collins, Colo. Samples were soaked in hot water and household bleach and rinsed through a 200 mesh Tyler standard screen to remove solubles and extremely small nondiagnostic particles (Holechek 1982). Each sample was transferred to 2 microscope slides. Equal amounts of sample were allocated to each slide by use of a template with a small hole. Hoyer's solution (Baker and Warten 1952) was applied to the slide and thoroughly mixed with the sample. Cover slides were then mounted. Twenty fields per slide of composite sample were examined at $100 \times$ magnification. Frequency addition procedures described by Holechek and Gross (1982) were used to calculate the percentage composition of undigested dietary components in the feces. Plant composition was categorized by species when possible. In some cases, however, only genera were determined.

\section{Statistical Analyses}

In all analyses, the dependent variables were percentages of a specific plant genera or species in fecal samples. Species or gen- era with low incidence $(<5 \%)$ exhibited bimodal or skewed distributions and were omitted from statistical analysis. Species utilized in analyses exhibited distributions which appeared normal.

Two statistical analyses were conducted by analysis of variance and covariance using the General Linear Models (GLM) procedures of SAS (1988). The first was used to investigate the effect of breed of cow or breed of calf on botanical composition of fecal samples. Data on cows and calves collected in October were analyzed separately. The experimental model for cow data in all 3 periods included the main effects of breed, age of cow and the interaction of age and breed. The experimental model for calf data included breed, sex of calf and the interaction of breed and sex of calf. Age of calf was included in preliminary analyses but was not an important source of variation and was therefore omitted from final analysis. Dependent variables included fecal nitrogen and phosphorus percentages as well as percentages of various plant gerera or species in fecal samples based on microhistology. Mean separation was conducted by the PDIFF option of the General Linear Models procedures (SAS 1988).

The second analysis was conducted to investigate the linear relationship between calf diets and the diets of their dams during the October sampling. A total of 53 cow-calf pairs were used $(9$ Angus, 34 Brangus, and 10 Hereford). The linear regression model included the discrete effect of calf sex and the continuous measurements taken on the dam (percentage fecal nitrogen and phosphorus and percentages of various species in the feces). Dependent variables were calf fecal nitrogen and phosphorus percentages as well as percentages of each plant genera or species in fecal samples based on fecal microhistology.

\section{Results}

Pasture forage composition is expressed as estimated standing crop biomass in Table 1. Total grass and forb standing crops were $783 \mathrm{~kg} / \mathrm{ha}$ (76.2\% grasses, $23.8 \%$ forbs), $552 \mathrm{~kg} / \mathrm{ha}$ (95.0\% grass-

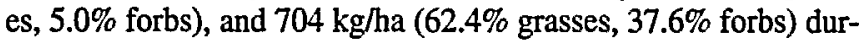
ing October 1991, January 1992, and July 1992, respectively. Shrub species were present but were not included in the estimates due to difficulty in accurately assessing shrub standing crop.

Breed $X$ age of cow and breed $X$ sex of calf interactions were not significant for any variable examined. Age and sex main effects were also non-significant for most variables.

\section{Effects of Breed on Diet Selection}

\section{Fall Measurements (October 1991).}

Least squares means for breed effects on botanical and chemical composition of fecal samples taken in October, 1991 are provided in Table 2. Aristida and Sporobolus were the most common grass genera identified by microhistology. Breed differences were found for the percentages of both grasses $(P<0.01)$ in feces of cows and suckling calves. Hereford cows exhibited a greater preference for Aristida than Angus and Brangus cows. Similarly, Hereford calves showed greater preference for Aristida than either Angus or Brangus calves. Conversely, Hereford cows showed less preference for Sporobolus than Brangus cows, while Hereford calves showed less preference for Sporobolus than Brangus and Angus calves. Although no other breed effects were 
Table 1. Raw means and plant species standing crop composition in study pasture in Oct., 1991 and Jan. and Jul., 1992.

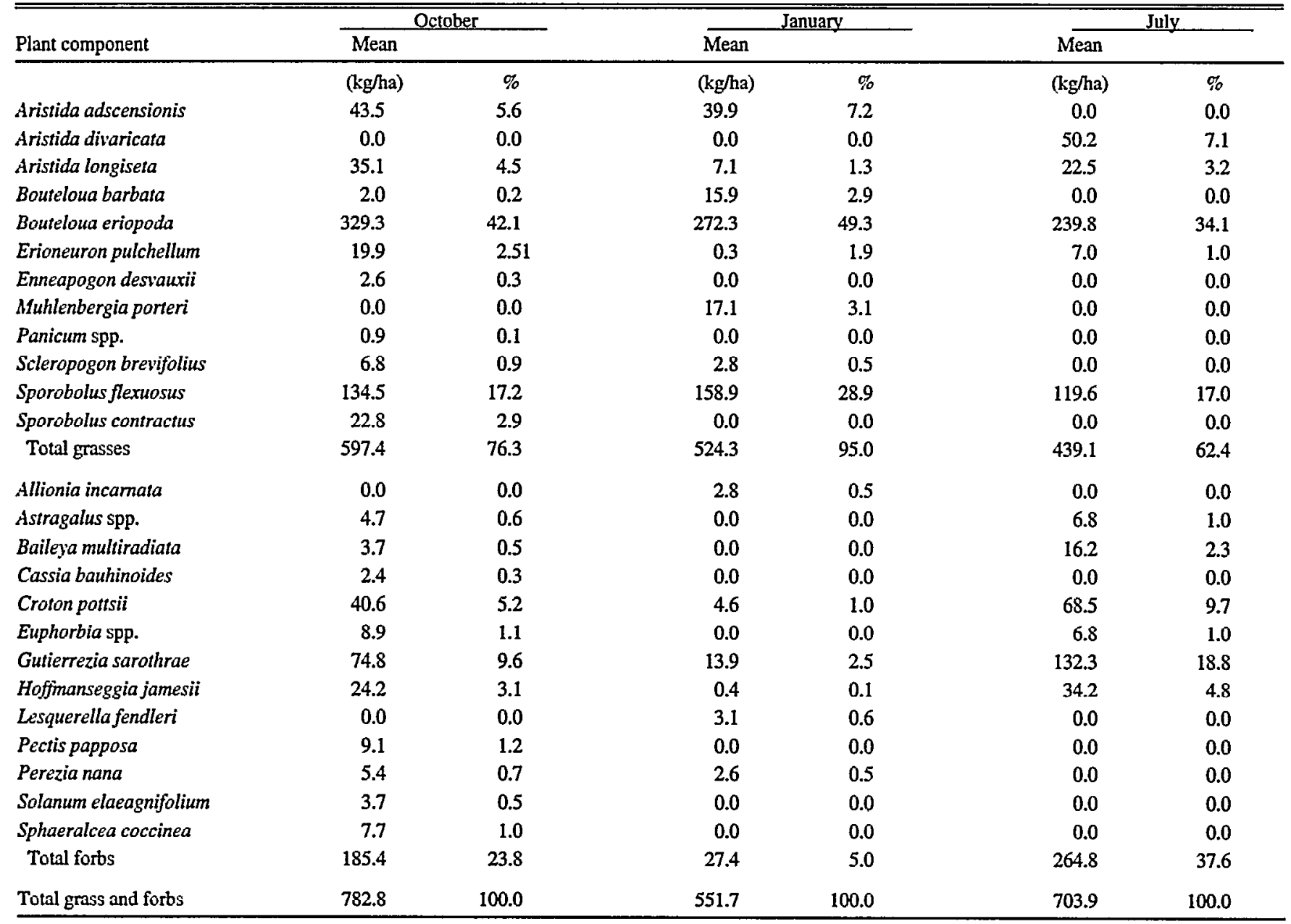

noted for this period, breed differences in preference for these major genera as well as similarities between breed effects on both cow and calf diets indicate that important genetic differences may exist during the fall season. Partial coefficients of determination for proportion of diets made up by Aristida and Sporobolus ranged from 0.17 to 0.28 . Herbel and Nelson (1966b) observed greater utilization of Aristida by Herefords than Santa Gertrudis during the fall season at a nearby location. They also indicated a slight preference by Santa Gertrudis for Sporobolus during the same period. The similarities between these findings suggests that Brahman influence (Brangus and Santa Gertrudis were developed with $5 / 8$ Brahman influence) may be affecting the utilization of these desert grasses.

Fecal nitrogen and phosphorus have been used as indicators of diet quality (Holechek et al. 1982). Breed of cow was an important source of variation for fecal phosphorus $(P<0.02)$. Feces from Hereford cows possessed more phosphorus than feccs from Angus and Brangus cows. This suggests that either Hereford cows were consuming a higher quality diet than either Angus or Brangus cows or that they differ in their ability to utilize dietary phosphorus. These differences in fecal phosphorus were not corroborated by fecal nitrogen levels $(P=0.59)$. Thus, it is difficult to conclude that differences in diet quality existed among the 3 breeds during October. Differences were observed in nitrogen content of calf fecal samples. However, this could be misleading because calf fecal chemistry may be affected by milk intake.

\section{Winter Measurements (January 1992).}

Cow breed differences were also found in January, 1992 (Table 3.). All three breeds were very dependent upon Bouteloua (primarily Bouteloua eriopoda) during this period. This is consistent with other results reported from this station (Rosierre ct al. 1975a; Rosierre et al. 1975b; Mohammad 1992). Hereford and Angus cows consumed a greater proportion of their diets as Bouteloua than did Brangus cows $(P<0.05)$. As in October, Brangus cows showed a greater preference for Sporobolus than Angus and Hereford cows. Angus cows exhibited greater preference for grasses than Brangus and Hereford cows. Brangus cows consumed substantial quantities of Yucca leaves during this period. Thus, the shrub component of Brangus diets appears to be important during the dormant winter months. Breed accounted for 12 to $31 \%$ of total variation in cow dietary composition in January. Fecal nitrogen and phosphorus were similar among the breeds.

\section{Summer Measurements (July 1992).}

Breed differences were also evident in July 1992 (Table 4.). Again Brangus cows showed a strong preference for Sporobolus. Diets of Brangus cows contained more total grasses than Angus 
Table 2. Breed least squares means for dietary components (based on fecal microhistology) and percentages of fecal organic matter composed of phosphorus and nitrogen for cows and suckling calves during Oct. 1991.

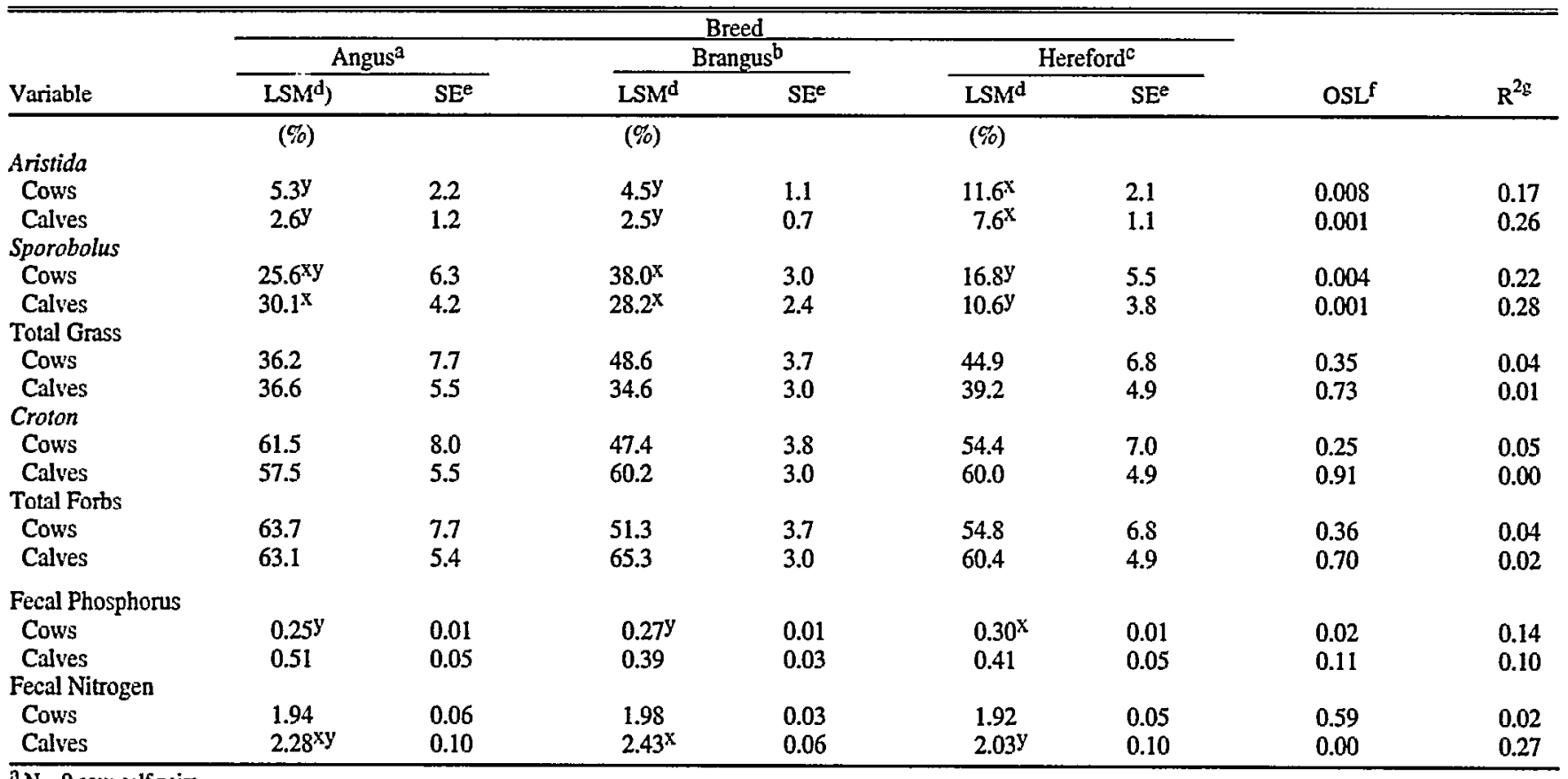

$\mathrm{N}=9$ cow-calf pairs.

$\mathrm{b}_{\mathrm{N}}=34$ cow-calf pairs.

$\mathrm{c} N=10$ cow-calf pairs.

d Least squares means.

e Standard error of least squares mean.

f Observed significance level of main effect (breed).

gPartial coefficient of determination associated with the main effect (breed).

cows. Higher percentages of Croton was found in Angus feces than Hereford or Brangus with Hereford cows having greater preference for Croton than Brangus. Breed accounted for $41 \%$ of the total variation in the Croton percentages in diets during the summer sampling. Angus cows also consumed a greater proportion of their diets as forbs than Brangus and Hereford cows. Herefurds had higher fecal nitrogen percentages than Brangus cows. No differences, however, were found in fecal phosphorus.

\section{Relationship Between Cow and Calf Diets}

Linear relationships among the botanical and chemical composition of dam and offspring diets are shown in Table 5. Relationships were found bětween percentages of Aristida $(P<$ $0.01)$ and Sporobolus $(P=0.06)$ in cow and calf samples. Calf preference for Aristida increased by an average of $0.23 \%$ for each $1 \%$ increase in Aristida in dams' preferences. Similarly, calf pref-

Table 3. Breed least squares means for dietary components (based on fecal microhistology) and percentages of fecal organic matter composed of phosphorus and nitrogen for cows in Jan. 1992.

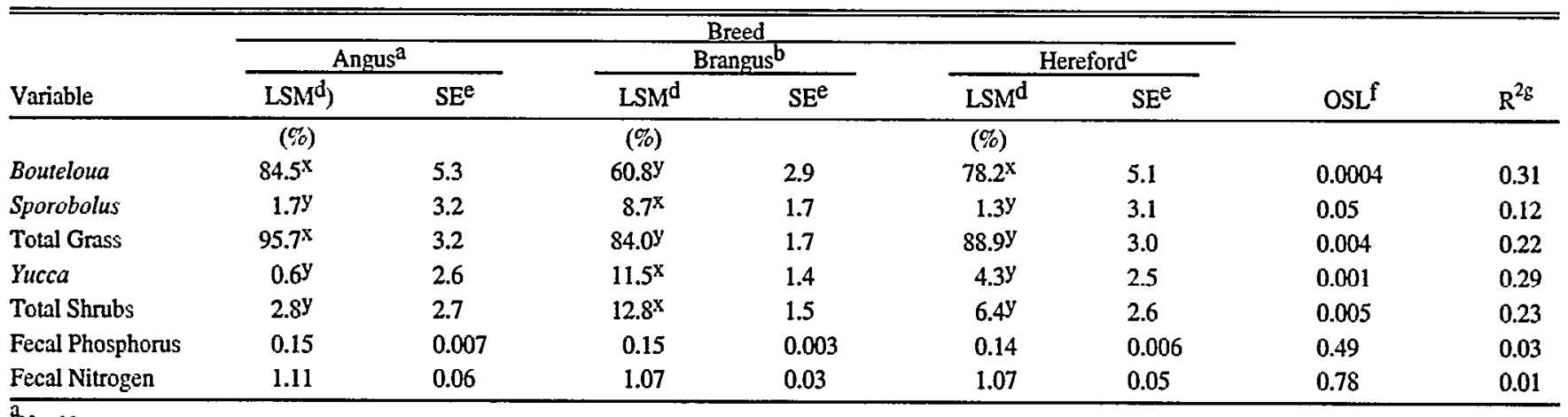

\footnotetext{
$\mathrm{N}=11$ cows.

$\mathrm{N}=37$ cows.

$\mathrm{N}=11$ cows.

Least squares means.

Standard error of least squares mean.

Observed significance level of main effect (breed)

${ }^{E}$ Partial coefficient of determination associated with the main effect (breed).

${ }^{x y z}$ Means within row with different superscripts are different $(P<0.05)$.
} 
Table 4. Breed least squares means for dietary components (based on fecal microhistology) and percentages of fecal organic matter composed of phosphorus and nitrogen for 4-6 year-old cows in Jul. 1992.

\begin{tabular}{|c|c|c|c|c|c|c|c|c|}
\hline \multirow[b]{3}{*}{ Variable } & \multicolumn{6}{|c|}{ Breed } & \multirow[b]{3}{*}{$\operatorname{OSL}^{\mathbf{f}}$} & \multirow[b]{3}{*}{$\mathrm{R}^{2 \mathrm{~g}}$} \\
\hline & \multicolumn{2}{|c|}{ Angus ${ }^{\mathrm{a}}$} & \multicolumn{2}{|c|}{ Brangus ${ }^{b}$} & \multicolumn{2}{|c|}{ Hereford ${ }^{c}$} & & \\
\hline & $\left.\mathrm{LSM}^{\mathrm{d}}\right)$ & $\mathrm{SE}^{e}$ & $\operatorname{LSM}^{\mathrm{d}}$ & $S^{e}$ & $\mathrm{LSM}^{\mathrm{d}}$ & $\mathrm{SE}^{\mathrm{e}}$ & & \\
\hline & $(\%)$ & & (\%) & & $(\%)$ & & & \\
\hline Bouteloua & 5.8 & 2.8 & 11.6 & 1.6 & 10.2 & 2.6 & 0.22 & 0.09 \\
\hline Sporobolus & $36.4^{\mathrm{y}}$ & 5.6 & $54.2^{x}$ & 3.1 & $44.7^{x}$ & 5.0 & 0.02 & 0.18 \\
\hline Total Grass & $55.7^{y}$ & 4.8 & $75.6^{x}$ & 2.7 & $69.9^{x}$ & 3.0 & 0.005 & 0.25 \\
\hline Croton & $39.7^{x}$ & 4.4 & $13.6^{2}$ & 2.4 & $24.9 y$ & 4.0 & 0.0001 & 0.41 \\
\hline Total Forbs & $43.8^{x}$ & 4.9 & $23.6^{y}$ & 2.7 & $29.5 y$ & 4.4 & 0.004 & 0.25 \\
\hline Fecal Phosphorus & 0.75 & 0.07 & 0.72 & 0.04 & 0.76 & 0.06 & 0.85 & 0.01 \\
\hline Fecal Nitrogen & $2.23 x y$ & 0.10 & $2.12^{y}$ & 0.06 & $2.44^{x}$ & 0.09 & 0.02 & 0.21 \\
\hline
\end{tabular}

aN $=11$ cows.

$\mathrm{bN}=37$ cows

cN $=11$ cows.

Least squares means (\%).

estandard ertor of least squares mean.

fobserved significance level of main effect (breed).

EPartial coefficient of determination associated with the main effect (breed).

xyz Means within row with different superscripts are different $(P<0.05)$.

erence for Sporobolus increased by $0.22 \%$ for each $1 \%$ increase in dams' preferences. However, partial coefficients of determination indicate that maternal diet composition was a minor factor affecting calf diet selection. No other linear relationships were observed between calf and cow botanical or chemical composition.

\section{Discussion and Conclusions}

Diet selection by free grazing cattle is a very complex, dynamic activity. It is complex in that diets may be composed of numerous plant species in varying quantities, and dynamic due to the changes in species composition and palatability over time. Differences in diet selectivity have been attributed to numerous factors including maternal training (Provenza and Balph 1987; Key and Maciver 1980), hunger (June and Koong 1985), past experience, age, smell, and social interaction with other individu-

Table 5. Linear regression of percentages of calf dietary components on similar measurements of their dams.

\begin{tabular}{|c|c|c|c|c|}
\hline Variable & Reg. Coef. ${ }^{b}$ & Standard Emorc & OSL $^{d}$ & $\mathrm{R}^{\mathrm{Ze}}$ \\
\hline & \multicolumn{4}{|c|}{$=(\%)-\ldots$} \\
\hline Aristida & 0.23 & 0.07 & 0.01 & 0.13 \\
\hline Sprorobolus & 0.22 & 0.06 & 0.06 & 0.07 \\
\hline Total Grass & 0.07 & 0.12 & 0.55 & 0.01 \\
\hline Craton & 0.04 & 0.12 & 0.71 & 0.00 \\
\hline Total Forbs & 0.07 & 0.12 & 0.55 & 0.01 \\
\hline Fecal Phos & 0.65 & 0.40 & 0.11 & 0.07 \\
\hline Fecal Nitro & 0.45 & 0.30 & 0.14 & 0.07 \\
\hline \multicolumn{5}{|c|}{$\begin{array}{l}\text { apercentage of each species in fecal samples based on microhistological examination or } \\
\text { percentage of fecal dry matter composed of nitrogen of phosphorus, } \mathrm{N}=53 \text { pairs. } \\
\text { bartial regression coefficient for the regression of calf measurements on similar mea- } \\
\text { surements on their dams. } \\
\text { cStandard error of regression coefficient. } \\
\text { dObsered significance level for the regression of calf measurements on measurements } \\
\text { on their dams. } \\
\text { e Partial coefficient of determination associated with the regression of calf measurements } \\
\text { on measurements of dams. }\end{array}$} \\
\hline
\end{tabular}

als (Lynch et al. 1992). Some have suggested that breed is also an important factor determining dietary composition of small ruminants (Arnold et al. 1981; Warren et al. 1984) and cattle (Herbel and Nelson 1966b).

Our results indicate that breed is an important factor determining species composition of cattle diets in the Chihuahuan Desert. We feel that these differences could be due to 2 possible behavioral responses.

First, we observed differences which we feel can be attributed to distances traveled from water during grazing activities. Our experimental pasture was large $(1,400 \mathrm{ha})$ and contained numerous plant species. Forage availability and species composition change with distance from water (Holechek et al. 1995). Highly palatable plants would be expected to occur at greater distances from water. Thus, cattle which travel greater distances should encounter these more palatable species with greater frequency. Plants which may fit into this scenario are of the genus Sporobolus. These species are often preferred to other major grass species at this location in summer and fall (Rosiere et al. 1975a; Ferrando 1990). In this study, Brangus cattle tended to consume a greater proportion of their diets as Sporobolus than Hereford or Angus cattle. Breeds with Brahman influence have been shown to graze further from water than British breeds (Herbel and Nelson 1966a). If Brangus cattle (a Brahman influenced breed) travel greater distances from water while grazing, they would be expected to consume greater quantities of such species.

The second cause of dietary variation among breeds may be that, given equal access, breeds simply prefer different plant species. This may explain why breed differences were also noted for species such as Yucca which was more uniformly distributed across the pasture. In this case, cattle would actively seek out the species of preference regardless of distance from water.

Precipitation during the study period was much above normal. This certainly affected forage availability and possibly forage species composition. Greater availability should result in less effort exerted by the grazing animal. If breeds differed due to differences in grazing aggressiveness, greater variation among breeds would be expected as forage availability declines. In this case, competition among animals would be expected to increase, 
and aggressive breeds (those which graze greater distances from water) would be expected to consume more palatable species in greater quantities. However, if dietary differences are a function of preference for specific plants, then greater breed differences would be expected in high versus low precipitation years. This would be due to enhanced variation of forage species allowing cattle to be more selective.

Though breed differences in diet selection observed among cows were consistent with differences observed among their suckling calves, we were unable to establish a strong direct link between the diet selection of dam and offspring during October. Calves were often observed grazing substantial distances from their dams, increasing dietary variation and reducing the relationship between the diets of cows and their calves.

We conclude that dietary differences exist among these breeds of cattle. However, more information is needed to assess the impact of breed of cattle on the utilization of range resources.

\section{Implications}

Stocking rates are usually established without consideration of the genetic makeup of the herd. These data suggest that important differences exist between breeds for diet botanical composition. Thus, the degree of utilization of certain plant communities may be affected by the breed composition of the herd. Variation in diet composition may be due to variation in actual preference for specific plants or due to differences in distance traveled from water while grazing. In either case, the type of cattle selected to graze a particular range site may affect the degree of utilization of major plant species or locations within the pastures. We believe an opportunity may exist to improve the utilization of large pastures if more can be learned about genetic control over grazing behavior and diet selection.

\section{Literature Cited}

AOAC. 1984. Official methods of analysis (14th Ed.) Assoc. of Official Anal. Chem.. Washington, D.C.

Arnold, G. W., S. R. Wallace, and W. A. Rea. 1981. The effect of age and breed on diet selection by sheep. Land Resources and Manage. Tech. Paper No. 9, 11, CSIRO, Australia.

Baker, E. W. and B. W. Warten. 1952. An introduction to acarology. MacMillan Co., N.Y.

Dabo, S. M., R. J. Tyrl, and F.O. Thetford. 1986. Identification of grass epidermal fragments. Okla. Agr. Exp. Sta. Rep. Proj. 1698.

Ferrando, C. A. 1990. Diet botanical composition and fecal indices of cows and steers on semidesert rangeland. M.S. Thesis, New Mexico State Univ., Las Cruces, N.M.

Herbel, C. H. and A. B. Nelson. 1966a. Activities of Hereford and Santa Gertrudis cattle on a southern New Mexico range. J. Range Manage. 19:173-176.

Herbel, C. H. and A. B. Nelson. 1966b. Species preference of Hereford and Santa Gertrudis cattle on southern New Mexico range. J. Range Manage. 19:177-181.

Holechek, J. L. 1982. Sample preparation technique for microhistological analysis. J. Range Manage. 35:267-268.

Holechek, J. L. and B. D. Gross. 1982. Training needed for quantifying simulated diets from fragmented range plants. J. Range Manage. 35:644-647.

Holechek, J. L., R. D. Pieper, and C. H. Herbel. 1995. Range Management Principles and Practices. Prentice-Hall, Englewood Cliffs, N.J.
Holechek, J. L., M. Vavra, and D. Arthun. 1982. Relationships between performance intake, diet nutritive quality and fecal nutritive quality of cattle on mountain range. J. Range Mange. 35:741-744.

Jung, H. G. and L. J. Koong. 1985. Effects of hunger satiation on diet quality by grazing sheep. J. Range Manage. 38:302-305.

Key, C. and R. M. Maclver. 1980. The effects of maternal influences on sheep: breed differences in grazing, resting and courtship behavior. Appl. Anim. Ethology 6:33-48.

Lynch, J. J., G. N. Hinch, and D. B. Adams. 1992. The behavior of sheep. Biological principles and implications for production. C.S.I.R.O. Pub., East Melbourne, Australia.

Mohammad, A.G. 1992. Effect of sex, genetic potential and season on botanical composition of cattle diets. M.S. Thesis. New Mexico State Univ., Las Cruces, N.M.

Provenza, F. D., and D. F. Balph. 1987. Diet learning by domestic ruminants: Theory, evidence, and practical implications. Appl. Anim. Behav. Sci. 18:211-232.

Rosierre, R. E., R. F. Beck, and J. D. Wallace. 1975a. Cattle diets on semidesert grassland: Botanical composition. J. Range Manage. 28:89-93.

Rosierre, R. E., J. D. Wallace, and R. F. Beck. 1975b. Cattle diets on semidesert grassland: nutritive content. J. Range Manage. 28:94-96.

SAS. 1988. SAS/STAT User's Guide (Release 6.03). SAS Inst. Inc., Cary, N.C.

Sparks, D.R. and J. C. Malechek. 1968. Estimating percentage dry weight in diets using a microscope technique. J. Range Manage. 21:264-265.

Taylor, R. E. 1994. Beef Production and Management Decisions (2nd Ed.). MacMillan Publishing Co., N.Y.

Walker, J. W., R. M. Hansen, and L. R. Rittenhouse. 1981. Diet selection of Hereford, Angus $x$ Hereford and Charolais $x$ Hereford cows and calves. J. Range Manage. 34:243-245.

Warren, L. E., D. N. Ueckert, and J. M. Shelton. 1984. Comparative diets of Rambouillet, Barbado and Karakul sheep and Spanish and Angora goats. J. Range Manage. 37:172-180. 